Research Article

\title{
EFFECT OF WC REINFORCED ON MICROSTRUCTURE AND MECHANICAL PROPERTIES OF CUALMN ALLOYS PRODUCED BY HOT PRESSING METHOD
}

\author{
Tayfun ÇETIN ${ }^{1}$, Mehmet AKKAŞ ${ }^{2 *}$
}

\begin{abstract}
In this study, the effect of WC reinforcing particles on the microstructure and mechanical properties of CuAlMn and CuAlMn-WC alloy produced by powder metallurgy method was investigated by adding $5 \%, 10 \%$ and $15 \%$ by volume WC to CuAlMn alloy. $\mathrm{Cu}, \mathrm{Al}, \mathrm{Mn}$ and WC powders of approximately $99.9 \%$ purity with a grain size of 325 mesh were used in the production of the alloys. The samples were produced by hot pressing method at $900{ }^{\circ}$ Ctemperatures under $35 \mathrm{MPa}$ pressure for 6 minutes. Microstructure, phase formation, hardness and corrosion properties of the samples were investigated in detail. Scanning electron microscopy (SEM) was used for microstructure analysis and X-ray diffractogram (XRD) was used for phase formation detection. The hardness measurements of the samples were measured by microhardness measuring device. The corrosion tests were performed potentiodynamic polarization curves of the composite materials in $3.5 \% \mathrm{NaCl}$ solution. As a result, it has been determined that the mechanical properties of WC reinforcing particles added to CuAlMn matrix increase with increasing volume ratio.
\end{abstract}

Key words: CuAlMn alloys, hot press, mechanical properties, microstructure properties, reinforced WC

\section{Introduction}

With the rapid development of technology, many new types of materials are being developed and used. These materials are more suitable for today's conditions and their usage is becoming widespread. Metal matrix composite materials have also been studied in recent years and new types of materials are derived. Production method with PM is a method used to produce full or semi-finished products [1]. It has been stated that some composite materials, such as super alloys and hard metals, can only be produced by the PM method, because the melting temperatures of the metals are very high and it is very difficult to reach these temperatures under industrial conditions [2,3,4]. Many different $\mathrm{Cu}$ alloys are used in the chemical industry and electro technologies [5-7]. $\mathrm{Cu}$ alloys have high corrosion and oxidation resistance in addition to their good thermal resistance and electrical resistance. In addition, copper has a good ductility and toughness [8]. Composites with $\mathrm{Cu}$ matrix have high thermal conductivity and electrical conductivity. In addition, the mechanical properties and tribological properties of these composites are good [9-12].

\footnotetext{
${ }^{1}$ Department of Electricity and Energy, Yüksekova Vocational School of Higher Education, Hakkari University, Hakkari, Turkey, (tayfuncetin@hakkari.edu.tr) (Dhttps://orcid.org/0000-0001-8060-344X

2 Department of Mechanical Engineering, Faculty of Engineering and Architecture, Kastamonu University, Kastamonu, Turkey, (mehmetakkas@kastamonu.edu.tr) Đhttps://orcid.org/0000-0002-0359-4743
} 
Metal matrix composites have many positive properties such as high elastic modulus, high strength and reproducibility [13]. In addition, these materials have very good abrasion resistance due to particle reinforcements [14,15]. There is also a lot of research on composites with copper matrix [16]. In a study, the abrasion resistance was improved by adding $\mathrm{Ni}_{3} \mathrm{Al}$ particles to the copper matrix [9]. $\mathrm{CuCr} \mathrm{SiC} \mathrm{composite} \mathrm{material} \mathrm{has} \mathrm{been} \mathrm{produced} \mathrm{and} \mathrm{it} \mathrm{has} \mathrm{been} \mathrm{stated} \mathrm{that} \mathrm{the} \mathrm{hardness} \mathrm{increases} \mathrm{in} \mathrm{the}$ examination [17]. In addition, FeMnp and $\mathrm{FeCrp}$ were added to the $\mathrm{Cu}$ matrix to investigate their microstructure and mechanical properties [18]. By adding different additions to the $\mathrm{Cu}$ matrix, its hardness, strength, abrasion resistance and conductivity can be improved [19]. In addition, tensile strength increased up to $4 \%$ within the varying $\mathrm{Cu}$ matrix ratios; It was observed that after $4 \%$ it decreased and the hardness increased with increasing $\mathrm{Cu}$ matrix ratio [20].

Although powder metallurgy (PM) is not a newly known process, it was only used as an industrial process in the early 20th century. PM method has been used extensively in different fields since the beginning. As an example to these; tool steels, stainless steels, superalloys, aluminum and titanium alloys, copper and copper alloys, nuclear materials and cermets can be given [1-5,21]. Parts produced by this method have a smoother surface than parts produced by other methods and often do not require secondary treatment. It was determined that approximately $97 \%$ of the first material used in mass production with PM was used. Accordingly, the production of the part is cheaper and in the desired composition, and some parts that are difficult to produce and process by other methods are easily produced. By making fluctuations on the value of the punch pressure, it is possible to produce products in various forms in a better quality and in a proper manner [4].

Demand increases for copper $(\mathrm{Cu})$ based alloys, especially $\mathrm{Cu}-\mathrm{Al}-\mathrm{Ni}, \mathrm{CuZn}-\mathrm{Al}$ and $\mathrm{Cu}-\mathrm{Al}-\mathrm{Mn}$ alloys due to their cheap cost and good shape recall effects and superelasticity in engineering applications [22-24]. Cu-based shape recall alloys have been in great demand after the 1960s and have been used as alternatives to NiTi alloys, because they have good electrical and thermal conductivity $[25,26]$. $\mathrm{Cu}$ based shape remembering alloy systems are in great demand in the practical applications of shape remembering alloys. Because it can be produced both cheaply and easily. However, as the high $\mathrm{Al}$ additive to this alloy causes the grain boundaries to weaken, it creates a very fragile alloy. It is important to add new elements to strengthen the $\mathrm{Cu}-\mathrm{Al}$ alloy with a good ductility [27,28]. The addition of new elements to $\mathrm{Cu}-\mathrm{Al}$ alloys made this alloy group more useful and attractive. However, in addition to the elementary additive, $\mathrm{CuAl}$ based shape recall alloys can improve the performance of the applied heat treatment. Generally, high temperature shape recall alloys are important in the robotics, automotive and aircraft industries. The application temperatures of these alloys should be above $390 \mathrm{~K}$ [29,30]. In this study, the effect of heat treatment temperature and heat treatment time on the conversion temperature and crystal structure of CuAlMn alloy, which is a new high temperature shape remember alloy, will be examined. There are some studies in the literature about the production of $\mathrm{Cu}-\mathrm{Al}-\mathrm{Mn}$ alloys with the PM method and the relationship between the microstructure and mechanical properties [31,32]. For example, Yu-Yang Gao et al. [33,34] in their study, they made a characterization study by adding different ratios of $\mathrm{SiC}$ to $\mathrm{Al}-\mathrm{Cu}-\mathrm{Mg}-\mathrm{Si}-\mathrm{Mn}$ composites by using PM method. They determined that the particles were dispersed homogeneously and the tensile strength increased. This has been linked to the formation of precipitates of $\mathrm{SiC}$ particles during sintering and post-sintering cooling. Yan et al. In their study, they investigated the change of martensitic phase by adding $\mathrm{Ni}$ to $\mathrm{Cu}-\mathrm{Al}-\mathrm{Mn}$ shape memory alloy casting method. They found that when $2 \% \mathrm{Ni}$ was added, the triple $\mathrm{Cu}-\mathrm{Al}-\mathrm{Mn}$ alloys increased the shape memory from $85 \%$ to $92 \%$. Cu-Al-Mn alloys have a high tensile strength. It is used in the production of 
machine parts, vehicles, lifting gear, railway wagons in constructions where high strength is required. Strength in Hardened State It has been determined that it reaches the strength of 52 steel [32].

\section{Experimental Procedure}

In the starting matrix powders, $\mathrm{Cu}, \mathrm{Al}, \mathrm{Mn}$ and $\mathrm{WC}$ an average particle size $44 \mu \mathrm{m}$ were used. The matrix in produced segments that was sintered by hot pressing process. Powder mixtures were weighed by using precision scales and mixing process was applied for 30 minutes by using a turbula mixer (Celmak Group 7T, Turkey). PEG 400 (Polyethylene Glycol) at a rate of 1,5 wt\% was added in the powder mixture in order to reduce friction forces during hot pressing and to provide a homogenized mixture. Previously, powders were weighed 20 grams, and then CuAlMn-WC were produced with a pressure of $300 \mathrm{MPa}$ by using double-effect hydraulic press (Dim-Net WP-45SA, Korea). After that, CuAlMn-WC were placed within graphite dies and hot pressed under vacuum atmosphere by a PLC controlled direct hot pressing machine (Zhengzhou Golden Highway, SMVB 80, China) (Fig. 1).

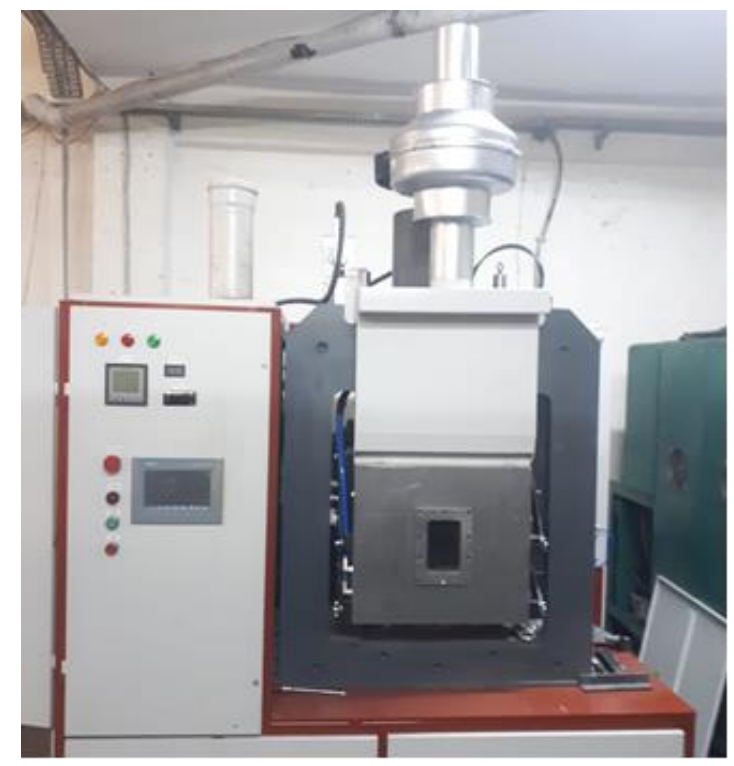

Figure 1. PLC controlled direct hot pressing machine.

Following that production process was completed by applying a sintering to the samples in a furnace (Prothem, PLF 120/27, Turkey) under argon atmosphere at $900{ }^{\circ} \mathrm{C}$ and under pressure $35 \mathrm{MPa}$ and for 4 minutes. Composite parameters of production were given in the Tab. 1.

Table 1. Hot pressing production parameters.

\begin{tabular}{|c|c|c|c|c|}
\hline Sample & Pressure (MPa) & Temperature $\left({ }^{\circ} \mathrm{C}\right)$ & Time (min.) & Chemical Composition \\
\hline 1 & \multirow{4}{*}{35} & \multirow{4}{*}{900} & \multirow{4}{*}{4} & $\mathrm{CuAlMn}$ \\
\hline 2 & & & & CuAlMn - $5 \%$ WC \\
\hline 3 & & & & CuAlMn - $10 \%$ WC \\
\hline 4 & & & & CuAlMn - $15 \%$ WC \\
\hline
\end{tabular}

The produced composite samples were characterized for hardness, optical microscope. Surface of the samples were polished with 200, 400, 600, 800, 1000 and 1200 mesh wet sandpaper by using grinding device (Metkon Forcimat, Turkey). Microhardness of the samples were measured in Vickers 
microhardness terms $\left(\mathrm{HV}_{0,1}\right)$ by using 16 second time and $0,1 \mathrm{~kg}$ of load. Surface of the samples were etched by a special etcher which consists of $50 \mathrm{gr}$. $\left(\mathrm{FeCl}_{3}-6 \mathrm{H}_{2} \mathrm{O}\right)+960 \mathrm{ml}$. methanol $+200 \mathrm{ml}$. HCI after polishing and then microstructure investigations were performed. The SEM images and EDS analyzes of the materials were obtained from the "FEI" brand "Quanta FEG 250" in model device at Kastamonu University Central Research Laboratories (Fig. 2a). The XRD analyzes of the samples were taken from "Bruker" brand "D8 Advance" model device at Kastamonu University Central Research Laboratories (Fig. 2b).
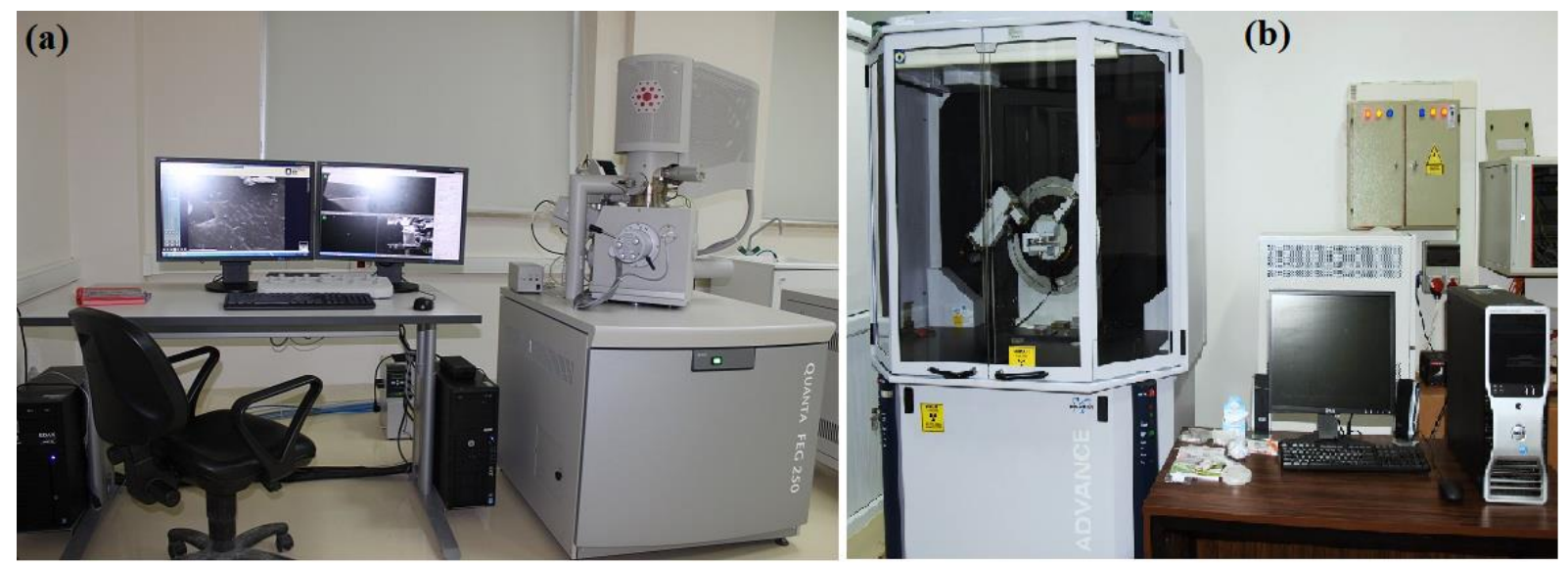

Figure 2. (a) FEI QUANTA 250 FEG SEM analyzer, (b) Bruker D8 Advance XRD analyzer.

The hardness measurements of the materials were done by using "SHIMADZU" brand "HMV G21" model microhardness measurement device (Fig. 3a) under 16 min. waiting time and $100 \mathrm{~g}$ load. Corrosion tests of the produced materials were made by "Gamry" brand Potentiostat / Galvanostat device (Fig. 3b).

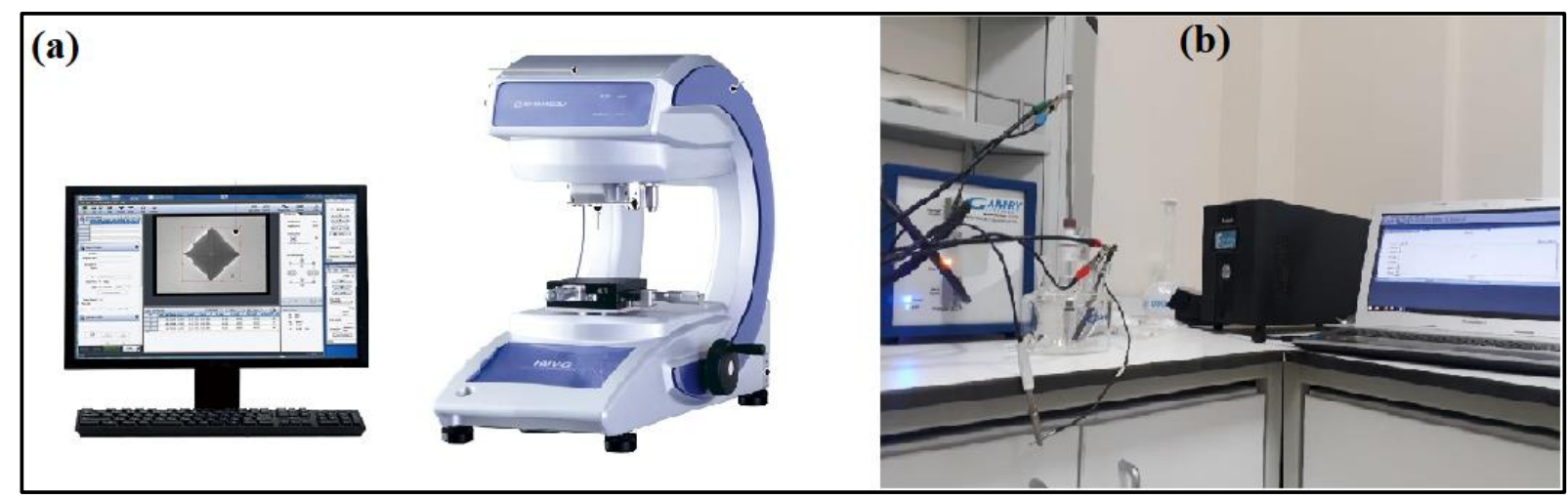

Figure 3. (a) SHIMADZU HMV-G21 model microhardness measuring device, (b) Reference 3000 Potentiostat / Galvanostat / ZRA device.

\section{Results and Discussion}

The SEM images of the CuAlMn-WC composites produced by the powder metallurgy method (Fig. 4) were taken and evaluations were made according to the obtained images.

When the SEM images are examined, it is seen that WC particles are distributed homogeneously in the interior of the sample containing CuAlMn. Samples produced are non-cracked and partially porous. As the addition of WC increases, the pore amount decreases and it is seen from SEM 
photographs. The homogeneous dispersion may be sufficient due to the sintering temperature [35]. Represents the WC powders are uniformly separated on the CuAlMn in the Fig. 4 [36].

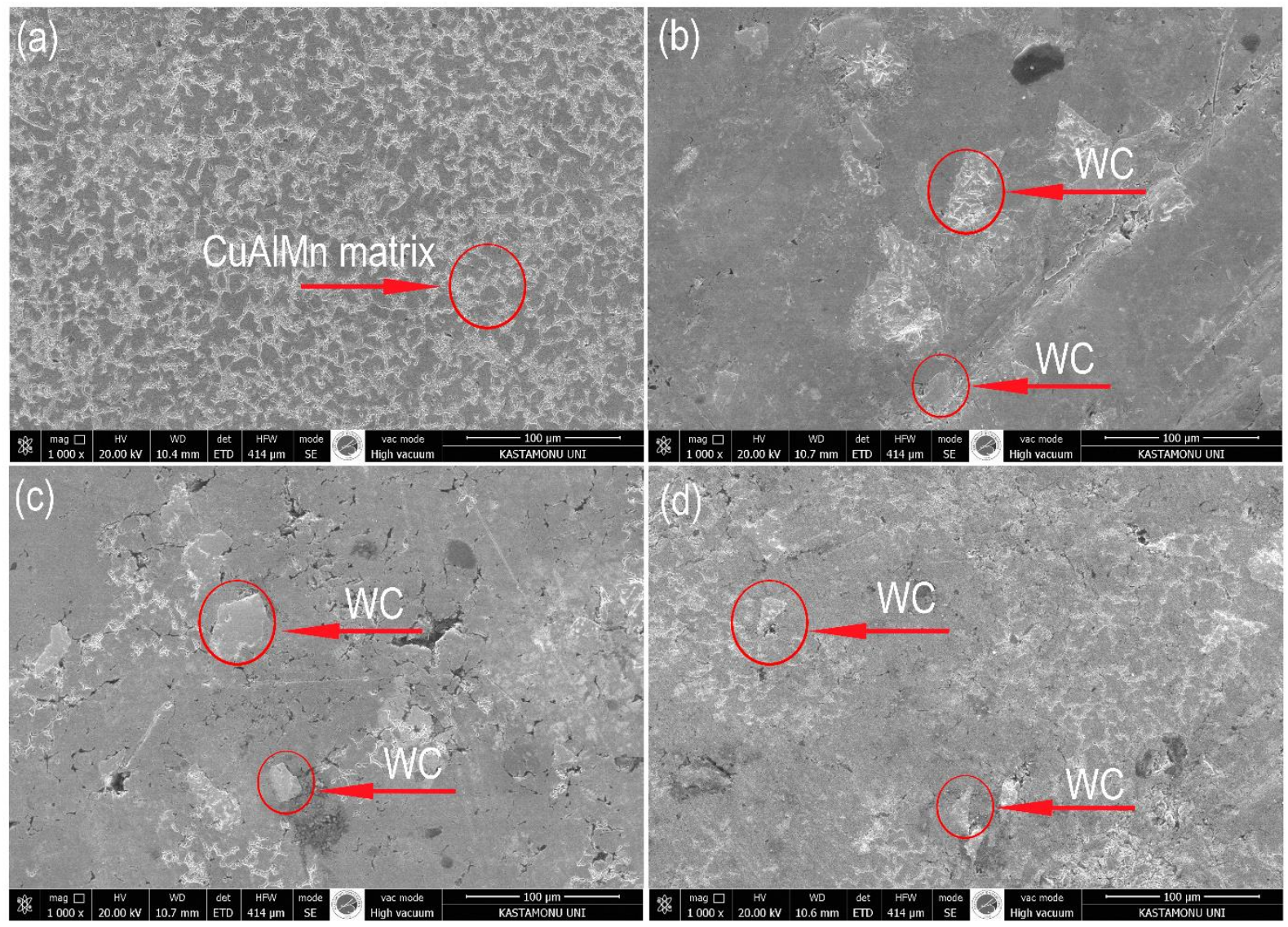

Figure 4. SEM images CuAIMn-WC composites produced: (a) CuAIMn, (b) CuAIMn - 5\% WC, (c) CuAIMn - 10\% WC and (d) CuAIMn - 15\% WC.

Fig. 5 shows hardness as a function of the WC content in the composites.

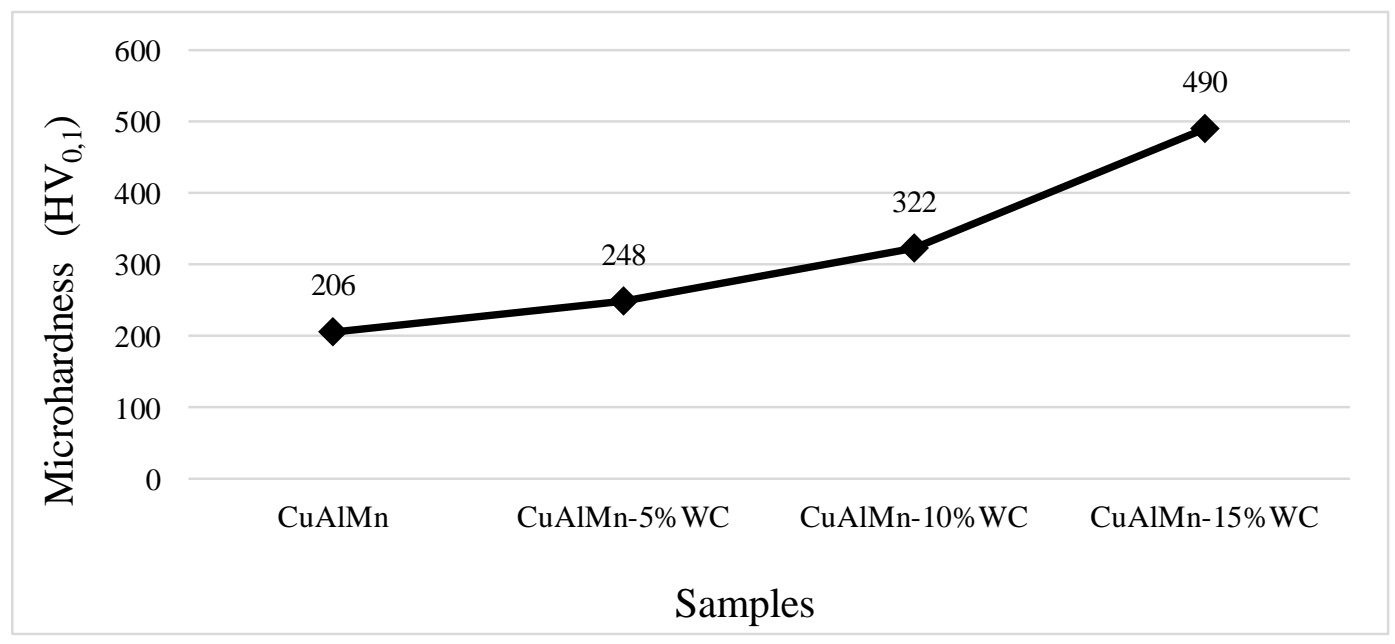

Figure 5. Microhardness graph of samples.

Hardness values were determined by taking the average of six different measurements on each composite. Hardness of the composites increased with increasing WC content. This may be explained by rule of mixture, applied to composite materials [37]. The hardness measurement values were 206 $\mathrm{HV}_{0,1}$ for CuAlMn, $248 \mathrm{HV}_{0,1}$ for CuAlMn - 5\% WC, $322 \mathrm{HV}_{0,1}$ for CuAlMn - 10\% WC and $490 \mathrm{HV}_{0,1}$ 
for CuAlMn $-15 \%$ WC. They are almost identical in the CuAlMn and CuAlMn $-5 \%$ WC hardness of composites by addition of WC. But CuAlMn $-15 \%$ WC composite is sharply increased in the hardness increased the amount of WC.

Fig. 6 shows SEM-EDS analysis taken from the samples.

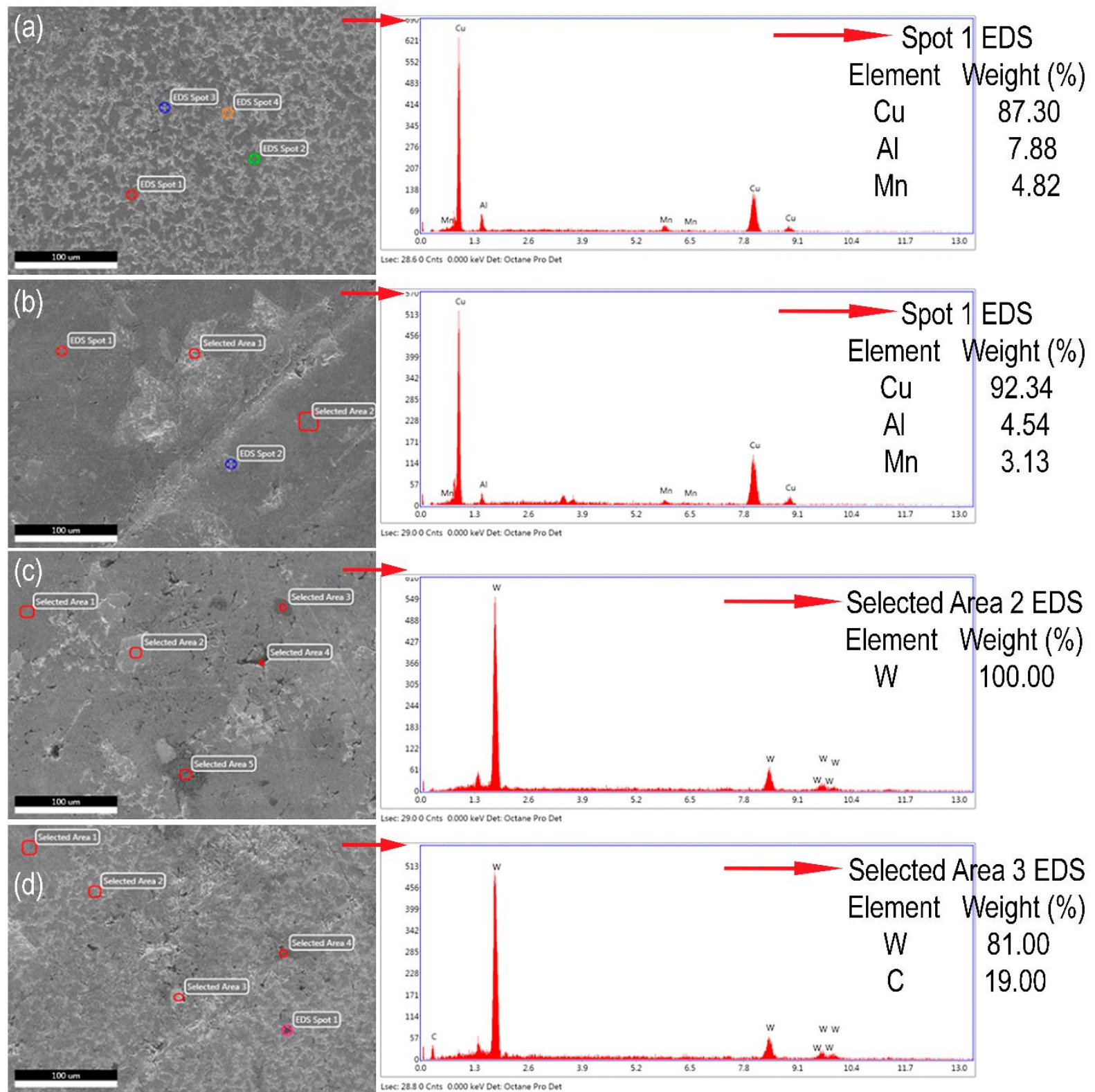

Figure 6. SEM-EDS analysis of the samples.

When the analysis results given in Fig. 6 were examined, it was figured out that the material was $\mathrm{CuAlMm}$ and WC. When the analysis results given in Fig. 6 were examined, the peaks of $\mathrm{Cu}, \mathrm{Al}, \mathrm{Mn}$, $\mathrm{W}$ and $\mathrm{C}$ that were present also in the samples were clearly seen. The matrix phase acquires a brighter backscattered electrons contrast level in splats where WC dissolution was more pronounced. Fig. 7 shows XRD graphs of the CuAlMn-WC composites produced by hot pressing method.

When the XRD graphs given in Fig. 7 were examined, the peaks of $\mathrm{Al}_{77} \mathrm{Mn}_{23}, \mathrm{Al}_{5} \mathrm{Cu}_{2} \mathrm{Mn}_{3}$, $\mathrm{AlCu}_{2} \mathrm{Mn}, \mathrm{AlCu}_{4}, \mathrm{Mn}, \mathrm{Al}_{8} \mathrm{Mn}_{5}, \mathrm{Cu}_{0.4} \mathrm{~W}_{0.6}$ and $\mathrm{WC}$ were determined. In this study, the phases formed are shown by XRD analysis; The formation of other phases has been revealed according to the results of EDS analysis.In their study on the effect of $\mathrm{CuAlMn} / \mathrm{WC}$ ratio on the plastic deformation in 
strengthening mechanism, Ji et al., determined similar peaks [38]. The dominant phases were seen to be $\mathrm{Al}_{77} \mathrm{Mn}_{23}, \mathrm{Al}_{5} \mathrm{Cu}_{2} \mathrm{Mn}_{3}, \mathrm{AlCu}_{2} \mathrm{Mn}$ and $\mathrm{AlCu}_{4}$ in the graphs. When all peaks were examined, it was found that as WC amount increased in the samples.

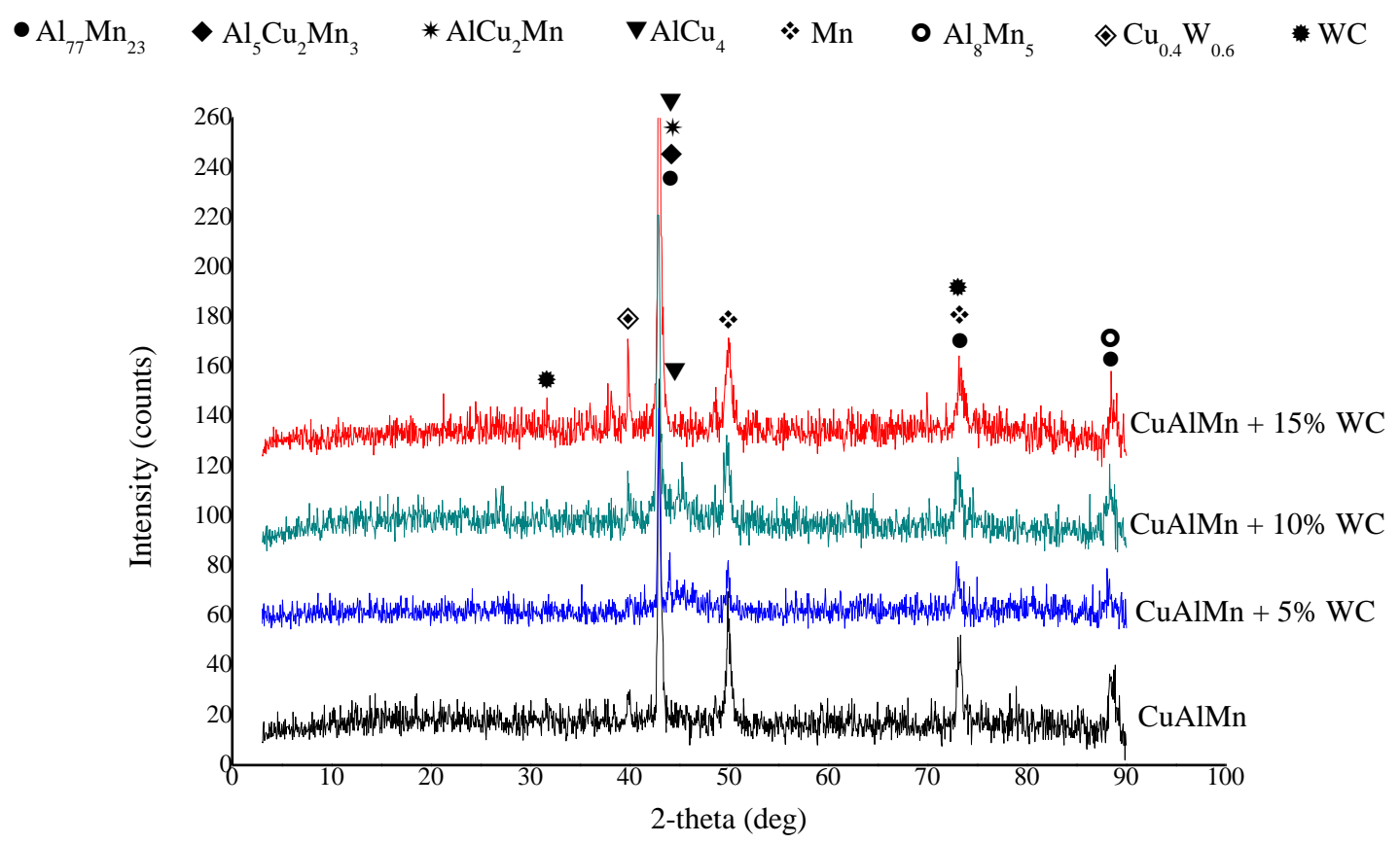

Figure 7. XRD graphs of the samples.

The corrosion tests of the samples were carried out in the prepared $3.5 \% \mathrm{NaCl}$ solution. Potentiodynamic polarization curves resulting from the experiments are given in Fig. 8.

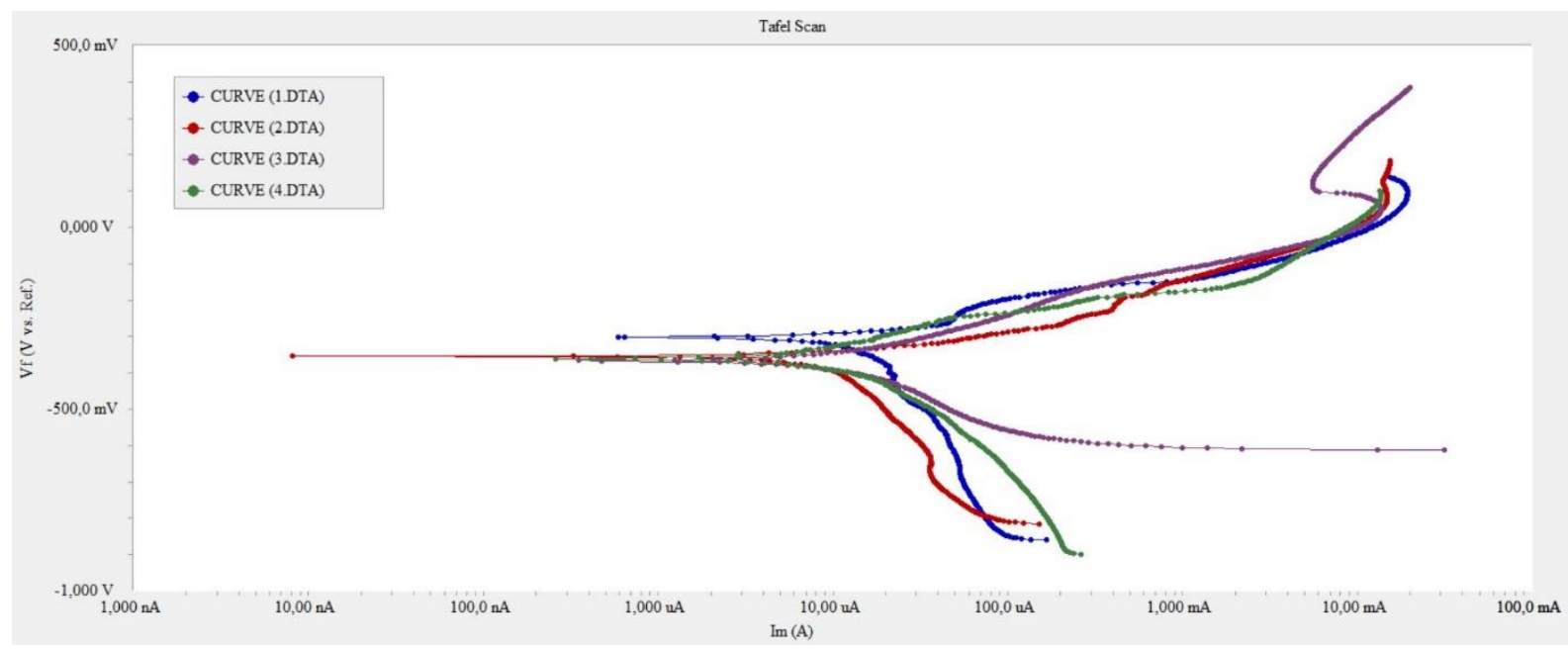

Figure 8. Tafel curves of samples.

The potential was applied to the open circuit potential after $-0.5 \mathrm{mV}$ to $0.5 \mathrm{mV}$. Immersion time of 30 minutes was applied. Ecorr (corrosion potential), Icorr (corrosion current), $\beta_{a}$ (anodic tafel curve), $\beta_{c}$ (cathodic tafel curve) and corrosion rate were determined from tafel curves. $\mathrm{R}_{\mathrm{p}}$ (corrosion resistance) was calculated using Stern and Geary equation (equation 1) [39].

$$
R_{p}=\frac{\beta_{a} \times \beta_{c}}{2.303 \times I_{\text {coor }}\left(\beta_{a}+\beta_{c}\right)}
$$


The electrochemical results of the samples are given in Tab. 2 .

Table 2. Electrochemical results of samples.

\begin{tabular}{ccccccc}
\hline Materials & $\begin{array}{c}\text { Ecorr } \\
(\mathbf{m V})\end{array}$ & $\begin{array}{c}\text { Icorr }(\boldsymbol{\mu A c m}- \\
\mathbf{2})\end{array}$ & $\boldsymbol{\beta a}(\mathbf{m V})$ & $\boldsymbol{\beta c}(\mathbf{m V})$ & $\begin{array}{c}\text { Corrosion } \\
\text { rate (mpy) }\end{array}$ & $\begin{array}{c}\mathbf{R}_{\mathbf{p}} \text { Corrosion } \\
\text { resistance }(\mathbf{k} \boldsymbol{\Omega} . \mathbf{c m} 2)\end{array}$ \\
\hline 1 & -302 & 16,72 & 95 & 512 & 10,76 & 2,08 \\
2 & -354 & 21,8 & 124 & 759,8 & 18,54 & 2,12 \\
3 & -367 & 10,5 & 127 & 188 & 10,23 & 3,13 \\
4 & -391 & 14,2 & 142,9 & 404,9 & 14,12 & 3,22 \\
\hline
\end{tabular}

As a result, there is a reaction between $\mathrm{Cu}, \mathrm{Al}, \mathrm{Mn}$ and $\mathrm{WC}$. When the Tab. 2 is examined, the $\mathrm{R}_{\mathrm{p}}$ (corrosion resistance) of the sample CuAlMn was $2.08 \mathrm{k} \Omega . \mathrm{cm}^{2}$, while the value for the sample CuAlMn $+5 \% \mathrm{WC}$ was calculated as $3.22 \mathrm{k} \Omega . \mathrm{cm}^{2}$. It is clear from the data obtained that as the amount of WC in the reinforced increases, the corrosion resistance of the samples increases. Similar results have been found in the literature for composites of reinforced WC [28].

\section{Conclusion}

The effects of WC on the microstructure and mechanical properties of composites fabricated by hot pressing were investigated.

- Microstructure observation demonstrates a relative homogenous distribution in CuAlMn of WC particulates.

- The hardness measurement values were $206 \mathrm{HV}_{0,1}$ for CuAlMn, $248 \mathrm{HV}_{0,1}$ for CuAlMn - 5\% $\mathrm{WC}, 322 \mathrm{HV}_{0,1}$ for CuAlMn - 10\% WC and $490 \mathrm{HV}_{0,1}$ for CuAlMn $-15 \% \mathrm{WC}$.

- The analysis of EDS the peaks of $\mathrm{Cu}, \mathrm{Al}, \mathrm{Mn}, \mathrm{W}$ and $\mathrm{C}$ that were present also in the samples were clearly seen.

- The dominant phases were seen to be $\mathrm{Al}_{77} \mathrm{Mn}_{23}, \mathrm{Al}_{5} \mathrm{Cu}_{2} \mathrm{Mn}_{3}, \mathrm{AlCu}_{2} \mathrm{Mn}$ and $\mathrm{AlCu}_{4}$ in the XRD graphs.

- It is clear from the data obtained that as the amount of WC in the reinforced increases, the corrosion resistance of the samples increases.

\section{Acknowledgment}

This work was supported by Scientific Research Projects Coordination Unit of Hakkari University. Project Number: FM19BAP4.

\section{References}

[1] Yılmaz, S.S. (2004). Demir esaslı T/M parçaların yüzey sertleştirme işlemlerinin fiziksel ve mekanik özelliklerine etkisi. Doktora Tezi, Celal Bayar Üniversitesi, Manisa, Türkiye.

[2] Lawley, A. (1992). Atomization: The Production Of Metal Powders. United States, Metal Powder Industries. 
[3] Turan H. and Sarttaş, S. (1994). Metal dust production with gas atomization. 6. International Machine Design and Manufacturing Congress, Ankara, Türkiye.

[4] Yılmaz, S.S., Ünlü, B.S. and Varol, R. (2008). Borlanmış ve bilyalı dövülmüş demir esaslı T/M malzemelerinin aşınma ve mekanik özellikleri. Makine Teknolojileri Elektronik Dergisi, pp. 7-16.

[5] Bargel, H.J. (1980). Werstoffkunde, VDI-Verlag.

[6] Tandon, K.N. and Tian, R.Z. (1993). Effect of $\mathrm{Pb}$ on the wear behavior of a $\mathrm{Cu}-\mathrm{Pb}$ alloy. Scripta Metallurgica et Materialia, vol. 29, pp. 857- 861.

[7] Barmouz, M., Asadi, P., Givi, M.K.B. and Taherishargh, M. (2011). Investigation of mechanical properties of $\mathrm{Cu} / \mathrm{SiC}$ composite fabricated by FSP: Effect of SiC particles' size and volume fraction. Material Science and Engineering: A, vol. 528, pp. 1740-1749.

[8] Barmouz, M., Givi M.K.B. and Seyfi, J. (2011). On the role of processing parameters in producing $\mathrm{Cu} / \mathrm{SiC}$ metal matrix composites via friction stir processing: Investigating microstructure, microhardness, wear and tensile behavior. Materials Characterization, vol. 62, pp. 108- 117.

[9] Chen, Z. Liu, P., Verhoeven J.D. and Gibson, E.D. (1996). Sliding wear behavior of deformationprocessed Cu-15vol.\%Cr in situ composites. Wear, vol. 195, pp. 214-222.

[10] Funkenbusch, P.D., Courtney, T.H. and Kubisch, D.G. (1984). Fabricability of an microstructural development in cold-worked metal matrix composites. Scripta Metallurgica et Materialia, vol. 18, pp. 1099- 1104.

[11] Nath, D., Biswas S.K. and Rohatgi P.K. (1980). Wear characteristics and bearing performance of aluminum-mica particulate composite-material. Wear, vol. 60, pp. 61-73.

[12] Saka, N. and Karalekas, D.P. (1985). Friction and wear of particle-reinforced metal ceramic composites. Proceedings of the International Conference on Wear of Materials, Canada.

[13] Muratoğlu, M. and Demirel, M. (2009). Influence of non-standart geometry of plastic gear on sliding velocities. 5. International Advanced Technologies Symposium, Karabük, Turkey.

[14] Alpas A.T. and Zhang, J. (1992). Effect of SiC particulate reinforcement on the Dry Sliding Wear of Aluminum Silicon Alloys (A356). Wear, vol. 155, pp. 83-104.

[15] Chen, R., Iwabuchi, A., Shimizu, T., Shin, H.S. and Mifune, H. (1997). The sliding wear resistance behavior of $\mathrm{NiAl}$ and $\mathrm{SiC}$ particles reinforced aluminum alloy matrix composites. Wear, vol. 213, pp. 175-184.

[16] Liang, Y.H., Zhao, Q., Zhang, Z.H., Li, X.J. and Ren, L.Q. (2014). Effect of B4C particle size on the reaction behavior of self-propagation high-temperature synthesis of TiC-TiB2 ceramic/Cu composites from a Cu-Ti-B4C system. International Journal of Refractory Metals and Hard Materials, vol. 46, pp. 71- 79 .

[17] Yonetken, A., Erol, A. and Kaplan, H. (2015). Microwave sintering and characterization of Cu-Cr$\mathrm{SiC}$ composite materials. 24th International Conference on Metallurgy and Materials Metal 2015, Brno, Czech Republic.

[18] Turhan, H., Yildiz T. and Gulenc, B. (2007). Microstructure and mechanical properties of Cu/Fe $\mathrm{Mnp}$ and $\mathrm{Cu} / \mathrm{FeCrp}$ matrix composites produced by powder metallurgy. Firat University Science and Engineering Magazine, vol.19, pp. 569-574.

[19] Callister, W.D. (2007). Materials Science And Engineering: An Introduction, John Wiley \& Sons.

[20] Bektaşoğlu A. and Savaşkan, T. (2005). Zn-60Al- (1-5) Cu alaşımlarının kuru sürtünme durumundaki aşınma özelliklerinin incelenmesi. Mühendis ve Makine, vol. 46, pp. 31-39. 
[21] Kilic, M., Kirik, I. and Okumus, M. (2017). Microstructure examination of functionally graded $\mathrm{NiTi} / \mathrm{NiAl} / \mathrm{Ni3Al}$ intermetallic compound produced by self-propagating high-temperature synthesis. Kovove Mater, 55, 97-106.

[22] Wang, C.P., Su, Y., Yang S.Y., Shi, Z. and Liu, X.J. (2014). A new type of Cu-Al-Ta shape memory alloy with high martensitic transformation temperature. Smart Mater. Struct. 23, 025018, $1-7$.

[23] Silva C.A. and Lima S.J. (2005). Evaluation of Mechanical Alloying to obtain Cu-Al-Nb Shape Memory Alloy. Mater. Res., 8-2, 169-172.

[24] Soliman, H.N. and Habib, N. (2014). Effect of ageing treatment on hardness of Cu-12.5 wt\% $\mathrm{Al}$ shape memory alloy. Indian J Phys, 88(8) 803-812.

[25] Kilic, M., Yenigun, B., Bati, S., Balalan, Z. and Kirik, I. (2019). Effect of Cu addition on porous NiTi SMAs produced by self-propagating high-temperature synthesis. Materials Testing, 61(12), 1140-1144.

[26] Camila, T.A., Rodrigo, E.C., Pedro, C. L., Carina, S.N., Erick, S.M., Murilo, S.S. and Gabriel K.C A. (2015). The effect of Chromium on microstructure of CuAlNi shape memory alloy. Jun 3rd 5th 2015, Brno, Czech Republic, EU.

[27] Firstov, G.S., Van Humbeeck, J. and Koval Y.N. (2004). High-temperature shape memory alloys Some recent developments. Mater. Sci. Eng. A, 378 2-10.

[28] Liu, N., Li, Z., Xu, G., Feng, Z., Gong, S., Zhu, L. and Liang, S. (2011). Effect of tellurium on machinability and mechanical property of CuAlMnZn shape memory alloy. Materials Science and Engineering: A, 528(27), 7956-7961.

[29] Giordana, M.F., Muñoz-Vásquez, N., GarroGonzález, M., Esquivel M.R. and Zelaya, E. (2015). Study of the formation of $\mathrm{Cu}-24 \mathrm{at} . \% \mathrm{Al}$ by reactive milling. Procedia Materials Science, 9, 262 270.

[30] Dasgupta, R., Kumar A., Kumar, P., Shahadat, H. and Abhishek P. (2014). Effect of alloying constituents on the martensitic phase formation in some Cu-based SMAs. J. Mater Res. Technol. 3(3) 264-273.

[31] Erden, M.A., Gündüz, S., Türkmen, M. and Karabulut, H. (2014). Microstructural characterization and mechanical properties of microalloyed powder metallurgy steels. Materials Science and Engineering: A, 616, 201-206.

[32] Erden, M.A., Gündüz, S., Karabulut, H. and Türkmen, M. (2016). Effect of vanadium addition on the microstructure and mechanical properties of low carbon micro-alloyed powder metallurgy steels. Materials Testing, 58(5), 433-437.

[33] Gao, Y.Y., Qiu, F., Geng, R., Zhao, W.X., Yang, D.L., Zuo, R. and Jiang, Q.C. (2018). Preparation and characterization of the $\mathrm{Al}-\mathrm{Cu}-\mathrm{Mg}-\mathrm{Si}-\mathrm{Mn}$ composites reinforced by different surface modified SiCp. Materials Characterization, 141, 156-162.

[34] Yang, Q., Yin, D.Q., Ge, J.Q., Chen, J., Wang, S.L., Peng, H.B. and Wen, Y.H. (2018). Suppressing heating rate-dependent martensitic stabilization in ductile $\mathrm{Cu}-\mathrm{Al}-\mathrm{Mn}$ shape memory alloys by $\mathrm{Ni}$ addition: An experimental and first-principles study. Materials Characterization, 145, 381-388.

[35] Liu, J., Chang, L., Liu, H., Li, Y., Yang, H. and Ruan, J. (2017). Microstructure, mechanical behavior and biocompatibility of powder metallurgy Nb-Ti-Ta alloys as biomedical material. Materials Science and Engineering: C, 71, 512-519. 
[36] Buytoz, S., Dagdelen, F., Islak, S., Kok, M., Kir, D. and Ercan, E. (2014). Effect of the TiC content on microstructure and thermal properties of $\mathrm{Cu}-\mathrm{TiC}$ composites prepared by powder metallurgy. Journal of Thermal Analysis and Calorimetry, 117(3), 1277-1283.

[37] Kim, H.S. (2000). On the rule of mixtures for the hardness of particle reinforced composites. Materials Science and Engineering: A, 289(1-2), 30-33.

[38] Ji, X., Wang, Q., Yin, F., Cui, C., Ji, P. and Hao, G. (2018). Fabrication and properties of novel porous $\mathrm{CuAlMn}$ shape memory alloys and polymer/CuAlMn composites. Composites Part A: Applied Science and Manufacturing, 107, 21-30.

[39] Stern, M. and Geary, A.L. (1957). Electrochemical polarization I. A theoretical analysis of the shape of polarization curves, Journal of the electrochemical society, 104(1), 56-63. 